Dapat diakses pada: http://jkb.ub.ac.id/index.php/jkb/article/view/2520

Jurnal Kedokteran Brawijaya Vol. 30, No. 4, Agustus 2019, pp. 235-239

Article History: Received 10 Januari 2019, Accepted 3 Juli 2019

Artikel Penelitian

\title{
Pengaruh Seduhan Tepung Kulit Mangga Manalagi (Mangifera Indica L.) terhadap Kadar MDA pada Tikus
}

\section{Effect of Brewed Indian Mango (Mangifera Indica L.) Skin Flour on MDA Levels in Rat}

\author{
Wardah Wilyanti, Fuadiyah Nila Kurniasari, Leny Budhi Harti \\ Departemen Gizi Fakultas Kedokteran Universitas Brawijaya Malang
}

\begin{abstract}
ABSTRAK
Diet tinggi lemak merupakan salah satu faktor yang dapat menyebakan stress oksidatif sehingga akan meningkatkan kadar Malondialdehid (MDA) didalam tubuh. Kadar MDA dipengaruhi oleh antioksidan salah satunya adalah polifenol yang terdapat pada kulit mangga manalagi. Penelitian ini bertujuan untuk mengetahui perbedaan kadar MDA pada tikus yang mendapatkan seduhan tepung kulit mangga manalagi. Metode yang digunakan dalam penelitian ini adalah true experimental dengan rancangan post test only control group design. Subjek pada penelitian ini adalah 30 tikus putih (Ratus Norvegicus Strain Wistar) jantan. Tikus dibagi menjadi 5 kelompok antara lain P0 (diet normal), P1 (diet tinggi lemak), P2, P3, dan P4 adalah tikus yang diberi diet tinggi lemak dan seduhan tepung kulit mangga manalagi dengan dosis sebesar 0,4 ; 0,8 ; dan 1,6 gram. Kadar MDA pada serum tikus diukur menggunakan spektrofotometer dengan panjang gelombang $532 \mathrm{~nm}$. Perbedaan kadar MDA dianalisis dengan menggunakan one way ANOVA. Hasil penelitian ini menunjukkan bahwa rata-rata kadar MDA P0, P1, P2, P3, P4 adalah 311,25, 371,75, 283,63, 323,00, dan 0,00ng/ml. Analisis statistik menunjukkan bahwa terdapat perbedaan yang signifikan kadar MDA pada kelompok P0 dengan $P 1$ ( $p=0,013)$. Kadar MDA kelompok P1 juga berbeda signifikan dengan P2 ( $p=0,001)$, namun tidak berbeda signifikan dengan P3 ( $p=0,159)$ dan kadar MDA P4 adalah 0,00ng/ml karena drop out. Kesimpulan dari penelitian ini adalah pemberian seduhan tepung kulit mangga manalagi dengan berat tepung 0,4 gram dapat menurunkan kadar MDA serum tikus putih yang diberi diet tinggi lemak.
\end{abstract}

Kata Kunci: Diet tinggi lemak, MDA, polifenol, tepung kulit mangga manalagi

\begin{abstract}
A high-fat diet is one of the factors that can cause oxidative stress, so Malondialdehyde (MDA) level in the body might increase. MDA level is influenced by antioxidants, one of which is polyphenols found in Indian mango skin. This study aimed to determine the differences in MDA levels in rats receiving brewed Indian mango skin flour. The study was true experimental with a post-test only control group design. The subject of this study were 30 male rats (Rattus Norvegicus Wistar Strain). The rats were divided into five groups; PO (normal diet), P1 (high-fat diet), P2, P3, and P4 (high-fat diet and three different doses of $0.4,0.8$, and 1.6 gram brewed Indian mango skin flour, respectively). MDA levels in rat serum were measured using a spectrophotometer with a wavelength of $532 \mathrm{~nm}$. The differences in MDA levels were analyzed using one-way ANOVA. The results of this study showed that the average levels of MDA among P0, P1, P2, P3, and P4 were $311.25 ; 371.75 ; 283.63 ; 323.00 ;$ and $0.00 \mathrm{ng} / \mathrm{ml}$ respectively. Statistical analysis showed there were significant differences in MDA levels between $P 0$ and $P 1$ group $(p=0.013)$. MDA levels in group $P 1$ were also significantly different from $P 2(p=$ $0.001)$, but not significantly different from P3 $(p=0.159)$ and the level of MDA in $P 4$ was $0.00 \mathrm{ng} / \mathrm{ml}$ because of drop out. This study concluded that brewed Indian mango skin flour from 0.4 gram mango skin flour could reduce the MDA level in rats receiving high-fat diet.
\end{abstract}

Keywords: High-fat diet, Indian mango skin flour, MDA, polyphenols

Korespondensi: Leny Budhi Harti. Departemen Gizi Fakultas Kedokteran Universitas Brawijaya Malang, JI. Veteran Malang 65145, Jawa TimurTel.(0341)551611Email: harti.lenybudhi@gmail.com

DOI: http://dx.doi.org/10.21776/ub.jkb.2019.030.04.1 


\section{PENDAHULUAN}

Persentase konsumsi lemak seseorang yang dianjurkan dalam sehari tidak lebih dari $25 \%$ total kebutuhan. Namun rata-rata konsumsi lemak masyarakat Indonesia pada tahun 2009 adalah sebesar 64,7 g/kapita/hari atau sekitar $29,1 \%$ dari rata-rata kebutuhan dalam sehari (1). Konsumsi lemak berlebihan terutama sumber lemak jenuh dapat menyebabkan kejadian dislipidemia dan meningkatkan resiko terjadinya penyakit kardiovaskuler. Di Indonesia, prevalensi dislipidemia sebesar 39,8\% (2).

Dislipidemia merupakan keadaan dimana terjadi ketidaknormalan metabolisme lipoprotein didalam tubuh (3). Dislipidemia dapat meningkatkan peroksidasi lipid dan penurunan aktivitas enzim antioksidan. Salah satu penanda terjadinya stres oksidatif adalah dengan meningkatnya kadar malondialdehid (MDA). Pada keadaan dislipidemia, kadar MDA dapat meningkat secara signifikan. Salah satu upaya untuk menurunkan kadar MDA adalah dengan antioksidan (4).

Mangga (Mangifera indica L.) adalah salah satu pangan lokal di Indonesia. Jumlah produksi mangga di Indonesia sebanyak 2.431 .330 ton atau $12,8 \%$ dari seluruh produksi buah di Indonesia pada tahun 2014. Buah mangga sendiri menjadi urutan kedua sebagai penyumbang terbanyak komoditi buah nasional (5). Salah satu jenis mangga yang paling sering dikonsumsi masyarakat adalah mangga manalagi. Mangga manalagi merupakan mangga yang banyak ditemukan di Jawa Timur. Mangga manalagi menempati urutan kedua jenis mangga dengan produksi mangga terbanyak di Jawa Timur setelah mangga gadung dengan total produk 58.357 buah pada tahun 2005-2008 (6). Salah satu bagian dari mangga yang kurang dimanfaatkan dengan baik adalah kulitnya. Dalam satu buah mangga utuh, sebesar $15-20 \%$ terdiri dari kulit buah. Kulit mangga yang sudah ditepungkan mengandung polifenol sebanyak $96,2 \mathrm{mg} / \mathrm{g}$ (7). Penelitian sebelumnya menunjukkan bahwa polifenol yang terdapat dalam mangga berfungsi sebagai antioksidan (free radical scavenger), namun tidak dijelaskan secara langsung efek tersebut terhadap penurunan kadar MDA yang merupakan salah satu marker radikal bebas $(8,9)$. Beberapa penelitian sebelumnya menjelaskan efek ekstrak polifenol terhadap penurunan peroksidasi lipid dan kadar MDA, namun bahan yang digunakan adalah Rosella dan Pomegranate. Hasil penelitian terebut menunjukkan bahwa ekstrak polifenol pada Rosella secara signifikan dapat menurunkan kadar MDA pada tikus model dibetes dan konsumsi suplementasi polifenol dari pomegranate sebanyak $1.506 \mathrm{mg}$ polifenol selama 4 minggu dapat menurunkan peroksidasi lipid secara signifikan pada pasien diabetes $(10,11)$. Tujuan dari penelitian ini adalah untuk mengetahui perbedaan kadar MDA pada tikus yang diberi seduhan tepung kulit mangga manalagi

\section{METODE}

\section{Rancangan Penelitian dan Desain Penelitian}

Penelitian ini merupakan penelitian true experimental dengan rancangan post test only control group design, yang dilaksanakan pada bulan Juli 2017 hingga Januari 2018, di Laboratorium Parasitologi dan Faal Fakultas Kedokteran Universitas Brawijaya. Penelitian ini telah mendapatkan persetujuan dari Komisi Etik Penelitian Kesehatan Fakultas Kedokteran Universitas Brawijaya dengan No.287/EC/KEPK-S1-GZ/08/2017

\section{Subjek Penelitian}

Subjek dari penelitian ini adalah 30 tikus (Ratus Norvegicus Strain Wistar) jantan, dengan berat badan 120-200 gram dan berumur 3-4 bulan. Tiga puluh ekor tikus dibagi dalam 5 kelompok perlakuan, dimana masing-masing kelompok perlakuan terdiri dari 6 ekor tikus termasuk tikus untuk estimasi dop out. Lima perlakuan tersebut antara lain PO (diet normal), P1 (diet tinggi lemak), P2, P3, dan P4 (diet tinggi lemak dan seduhan tepung kulit mangga manalagi dengan berat tepung sebesar $0,4,0,8$, dan 1,6 gram per hari. Tikus yang mati selama penelitian akan didrop out .

\section{Pembuatan Seduhan Tepung Kulit Mangga Manalagi}

Tepung kulit mangga manalagi dibuat dengan memodifikasi prosedur pada penelitian sebelumnya (12). Pertama, kulit mangga manalagi yang telah dikupas dicuci bersih menggunakan air mengalir dan setelah itu diletakkan dan dijajar rapi di atas nampan. Kemudian kulit mangga dikeringkan dengan suhu $100^{\circ} \mathrm{C}$ menggunakan oven selama kurang lebih 3 jam. Kulit mangga yang telah kering kemudian dihancurkan menggunakan blender hingga menjadi bubuk, kemudian diayak menggunakan ayakan tepung

\section{Prosedur Penelitian}

Ada 11 tahap dalam penelitian ini, adapun tahapantahapan penelitian ini antara lain: 1.) Pembuatan tepung kulit mangga, 2.) Uji polifenol tepung kulit mangga, 3.) Penimbangan berat badan tikus, 4.) Tikus diadaptasi selama 7 hari dan diberi makanan diet normal secara ad libitum serta dikandangkan dengan kandang yang berbeda, 5.) Penimbangan berat badan tikus, 6.) Tikus dibagi secara acak menjadi 5 kelompok, yaitu P0, P1, P2, P3, dan P4, 7.) $P 0$ diberikan diet normal sebanyak 40 gram dan $5 \mathrm{ml}$ aquade (sebagai placebo), P1 diberikan diet tinggi lemak sebanyak 40 gram dan $5 \mathrm{ml}$ aquades (sebagai placebo), P2, P3, dan P4 diberikan diet tinggi lemak sebanyak 40gram dan $5 \mathrm{ml}$ seduhan tepung kulit mangga manalagi dengan berat tepung $0,4,0,8$, dan 1,6gram. Diet normal dan diet tinggi lemak diberikan secara ad libitum dan seduhan tepung kulit mangga manalagi dan akuades yang berfungsi sebagai placebo diberikan secara sonde sebanyak 2 kali yaitu pukul 08.30 WIB dan 16.00 WIB, 8.) Sisa pakan ditimbang setiap hari, 9.) Berat badan tikus setiap 1 minggu sekali, 10.) Hari ke 43 tikus dibius menggunakan inhalasi eter dan dikorbankan untuk diambil sampel darahnya dari jantung sebanyak $5 \mathrm{ml}, 11$.) Uji MDA.

\section{Uji Polifenol Tepung Kulit Mangga Manalagi}

Pengujian kadar total fenol dengan metode FolinCiocalteus modifikasi. Sampel sebanyak $25 \mu \mathrm{L}$ dimasukkan ke tabung reaksi. Kemudian ditambahkan reagen FolinCiocalteu $10 \%$ sebanyak $1 \mathrm{~mL}$ dan dihomogenkan. Setelah itu, ditambahkan $\mathrm{Na}_{2} \mathrm{CO}_{3} 7,5 \%$ sebanyak $2 \mathrm{~mL}$ dan akuades hingga $10 \mathrm{~mL}$ yang kemudian dihomogenkan dan didiamkan selama 15 menit pada suhu ruang. Larutan tersebut diukur absorbansinya pada $\lambda \max =760 \mathrm{~nm}$.

\section{Pengujian Kadar MDA}

Pengujian kadar MDA menggunakan metode spektrofotometri (13). Pertama sampel darah diambil sebanyak $5 \mathrm{ml}$ kemudian disentrifugasi selama 10 menit dengan suhu $4^{\circ} \mathrm{C}$ dan diambil serum darahnya. Serum darah ditambahkan dengan TBA reagen sebanyak $0,5 \mathrm{ml}$ dan dipanaskan ke dalam waterbath dengan suhu $90^{\circ} \mathrm{C}$ - 
$100^{\circ} \mathrm{C}$ selama kurang lebih 1 jam. Supernatan yang diperoleh kemudian diukur absorbansinya menggunakan spektrofotometer dengan panjang gelombang $532 \mathrm{~nm}$.

\section{Analisa Data}

Uji normalitas dilakukan dengan menggunakan ShapiroWilk Test. Perbedaan kadar MDA dianalisis dengan menggunakan one way ANOVA yang dilanjutkan dengan uji Post Hoc untuk menentukan kelompok mana yang berbeda. Perbedaan asupan pakan dianalisis menggunakan Kruskal Wallis pada software SPSS 16.0 for Windows $X P$.

\section{HASIL}

Rata-rata kadar MDA dari semua sampel pada penelitian ini dapat dilihat pada Tabel 1.

Tabel 1. Rata-rata \pm SD kadar MDA tiap kelompok perlakuan

\begin{tabular}{ccr}
\hline Kelompok Perlakuan & Jumlah $(\mathbf{n})$ & Kadar MDA $(\mathbf{n g} / \mathbf{m L})$ \\
\hline P0 & 5 & $311,25 \pm 22,67^{\mathrm{a}}$ \\
P1 & 5 & $371,75 \pm 27,44^{\mathrm{b}}$ \\
P2 & 4 & $283,63 \pm 29,54^{\mathrm{a}}$ \\
P3 & 3 & $323,00 \pm 30,05^{\mathrm{ab}}$ \\
P4 & 0 & 0,00 \\
\hline
\end{tabular}

Keterangan: Kode ${ }^{\mathrm{a}, \mathrm{b}}$ menunjukkan perbedaan bermakna dari hasil uji statistik

Hasil uji normalitas dengan Shapiro-Wilk test menunjukkan bahwa data berdistribusi normal ( $p=0,807)$. Analisis statistik dengan menggunakan ANOVA menunjukkan bahwa rata-rata kadar MDA antara 5 kelompok perlakuan berbeda signifikan $(p=0,002)$. Hasil uji Pos Hoc Tukey menunjukkan bahwa terdapat perbedaan yang signifikan kadar MDA pada kelompok PO dengan P1 $(p=0,013)$. Kadar MDA kelompok P1 juga berbeda signifikan dengan $P 2(p=0,001)$, namun tidak berbeda signifikan dengan P3 $(p=0,159)$ dan kadar MDA $\mathrm{P} 4$ adalah 0,00ng/ml karena drop out .

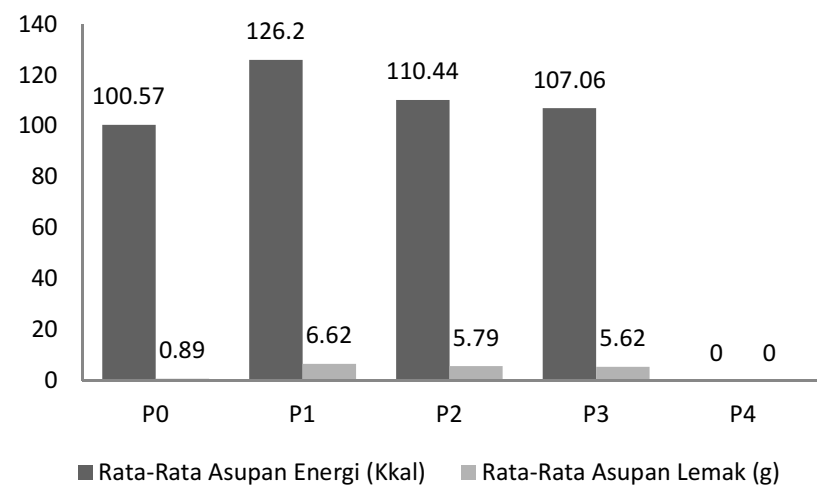

Gambar 1. Rata-rata asupan energi dan lemak

Hasil uji normalitas dengan Shapiro-Wilk test menunjukkan bahwa data berdistribusi tidak normal $(p<0,05)$. Analisis statistik dengan menggunakan Kruskal Wallis menunjukkan bahwa rata-rata asupan energi dan lemak antara 5 kelompok perlakuan berbeda signifikan $(p=0,024$ dan $p=0,008)$.

\section{DISKUSI}

Tikus yang mendapatkan diet tinggi lemak secara signifikan memiliki kadar MDA yang lebih tinggi jika dibandingkan dengan tikus yang mendapatkan diet normal. Pada penelitian ini asupan lemak dan energi tergambar dalam Gambar 1, dimana asupan lemak pada tikus kelompok P1 paling tinggi jika dibandingkan dengan kelompok lain. Diet tinggi lemak menyebabkan keadaan dislipidemia, yaitu keadaan dimana terjadi ketidakseimbangan kadar lipid didalam tubuh. Keadaan ini akan menyebabkan tubuh mengalami inflamasi. Inflamasi ini terjadi karena adanya pengeluaran sitokin-sitokin proinflamasi yang tidak terkontrol (14). Akibatnya, tubuh akan mengalami stres oksidasi yang ditandai dengan meningkatnya kadar ROS didalam tubuh. ROS ini sendiri dapat mengeluarkan efek sitotoksiknya akibat adanya kadar lipid yang sangat tinggi (4). Munculnya keadaan stres oksidasi didalam tubuh dapat mengoksidasi jaringan tubuh, salah satunya adalah lipid. Lipid yang teroksidasi oleh radikal bebas akan menyebabkan terjadinya peroksidasi lipid dan membentuk sebuah senyawa karbonil, yaitu MDA (15).

Tikus yang mendapatkan diet tinggi lemak dan seduhan tepung kulit mangga manalagi dengan berat tepung 0,4gram (P2), secara signifikan memiliki kadar MDA yang lebih rendah dibandingkan tikus yang hanya mendapatkan diet tinggi lemak saja (P1). Hal ini disebabkan kerena asupan lemak kelompok P2 lebih rendah dibandingkan dengan P1 dan kelompok P2 mendapatkan sonde seduhan tepung kulit mangga. Pemberian seduhan tepung kulit mangga manalagi ini dapat menyebabkan penurunan kadar MDA didalam tubuh. Hal ini disebabkan karena kandungan antioksidan, yaitu polifenol yang terkandung didalam tepung kulit mangga manalagi. Berdasarkan hasil uji laboratorium polifenol, diketahui bahwa dalam 100 gram tepung kulit mangga manalagi memiliki kandungan polifenol sebesar $181,411 \mathrm{mg} / \mathrm{L}$. Kadar polifenol yang diberikan pada kelompok P2 sebesar $67,75 \mathrm{mg}$, yang mana dosis tersebut masih dalam rentang efektifitas dosis kerja polifenol. Hal ini sejalan dengan penelitian sebelumnya yang menyebutkan bahwa dosis polifenol yang efektif dalam menurunkan kadar MDA pada manusia adalah $1506 \mathrm{mg}$ atau setara dengan $27,1 \mathrm{mg}$ pada tikus dan dengan menggunakan dosis polifenol sebesar $1506 \mathrm{mg}$, maka kadar MDA dapat turun dari $1,75 \mu \mathrm{M}$ menjadi $1 \mu \mathrm{M}$ (8). Pada penelitian ini, dengan menggunakan polifenol sebesar 67,75mg dapat menurunkan kadar MDA sebesar $88,125 \mathrm{ng} / \mathrm{mL}$. Polifenol juga dapat berperan sebagai scavanger dari radikal hidroksil dan superoksida dan chelator dari unsur-unsur transien. Pada keadaan dislipdemia, polifenol dapat berfungsi sebagai pencegah agregasi dari platelet dengan cara mengahambat pengeluaran aktivitas cyclooxygenase 1 (COOX-1) sehingga akan menghambat sintesa thromboxane $A 2$, dimana senyawa ini dapat menghasilkan MDA (16).

Tikus yang mendapatkan diet tinggi lemak dan seduhan tepung kulit mangga manalagi dengan berat tepung 0,8 gram (P3) memiliki kadar MDA yang lebih rendah jika dibandingkan dengan tikus yang mendapatkan diet tinggi lemak saja (P1) meskipun secara statistik tidak berbeda signifikan. Hal ini disebabkan karena asupan lemak kelompok P3 lebih rendah dibandingkan kelompok P1 dan P3 mendapatkan sonde seduhan kulit tepung mangga, akan tetapi kadar MDA nya lebih tinggi jika dibandingkan dengan tikus yang mendapatkan diet tinggi lemak dan 
seduhan tepung kulit mangga manalagi dengan berat tepung 0,4 gram (P2). Hal ini bisa disebabkan karena adanya perubahan antioksidan polifenol menjadi prooksidan. Antioksidan yang terlalu tinggi jumlahnya akan berpengaruh pada laju oksidasi, dimana aktivitas antioksidan akan hilang dan berubah menjadi pro oksidan. Perubahan ini terjadi terutama pada kelompok fenolik (17). Dengan terbentuknya pro oksidan maka dapat menyebabkan terjadinya stres oksidatif didalam tubuh. Apabila terjadi stres oksidatif, maka lipid dapat teroksidasi dan akhirnya terbentuklah MDA (15).

Rata-rata kadar MDA kelompok perlakuan P4 adalah $0,00 \mathrm{ng} / \mathrm{ml}$, hal ini disebabkan karena semua subjek penelitian pada kelompok P4 drop out karena mati. Pada penelitian jumlah tikus yang drop out karena mati sebanyak 13 ekor. Sebelum subjek penelitian drop out, ditemukan tanda-tanda sebagai berikut: lemas setelah disonde seduhan kulit mangga manalagi dan placebo (aquades), berat badan menurun, asupan makan menurun, dan perut membesar akan tetapi tidak dilakukan autopsi untuk mengetahui penyebab kematian tikus. Hal ini sejalan dengan penelitian sebelumnya dimana penelitian dengan menggunakan hewan coba juga mengalami drop out (mati), namun drop out (mati) disebabkan karena diare (18).

Sonde secara oral meningkatkan mortalitas pada hewan coba, hal ini berkaitan dengan tingginya resiko reflux. Kondisi stres fisik juga terjadi pada tikus yang mendapatkan sonde secara oral tanpa pembiusan, hal ini disebabkan saat pemberian sonde terjadi ketegangan/pengekangan pada tikus, jika ketegangan terjada antara 15-50 detik maka akan memicu stres pada tikus, oleh karena itu sonde diberikan tidak boleh melebihi 2 detik $(19,20)$, namun pada penelitian ini durasi waktu pemberian sonde secara oral tidak diamati. Pemberian sonde secara oral tanpa melalui pembiusan juga berdampak pada penurunan berat badan, pada penelitian yang dilakukan oleh Jones et al., menunjukkan bahwa sonde secara oral menurunkan berat badan pada mencit (21). Penurunan berat badan tikus juga terjadi pada penelitian ini, dimana sebelum mati tikus mengalami penurunan berat badan. Faktor lain yang meningkatkan mortalitas tikus sebagai hewan coba adalah karakteristik cairan yang diberikan melalui sonde oral. Karakteristik

\section{DAFTAR PUSTAKA}

1. Hardinsyah. Analisis Konsumsi Lemak, Gula, dan Garam Penduduk Indonesia. Jurnal Gizi Indonesia. 2011; 34(2): 92-100.

2. Chiu S, Williams PT, and Krauss RM. Effects of a Very High Saturated Fat Diet on LDL Particles in Adults with Atherogenic Dyslipidemia: A Randomized Controlled Trial. PLoS ONE. 2017; 12(2): 1-14.

3. Zaki I, Johan A, dan Widyastiti NS. Pengaruh Pemberian Jus Mangga terhadap Profil Lipid dan Malondialdehyde pada Tikus yang Diberi Minyak Jelantah. Jurnal Gizi Indonesia. 2015; 3(2): 108-115.

4. RL Yang, Shi YH, Hao G, Li W, and Le GW. Increasing Oxidative Stress with Progressive Hyperlipidemia in Human: Relation between Malondialdehyde and Atherogenic Index. Journal of Clinical Biochemistry and Nutrition. 2008; 43(3): 154-158. cairan tersebut antara lain: jumlah, $\mathrm{pH}$, dan osmolaritas. Jumlah cairan yang diberikan secara sonde dan bisa ditoleransi tikus sebanyak $5 \mathrm{ml} / \mathrm{kg}$ berat badan (22). Pada penelitian ini jumlah aquades sebagai placebo dan seduhan tepung kulit mangga manalagi sudah sesuai dengan penelitian sebelumnya yaitu $5 \mathrm{ml} /$ hari. Cairan yang bersifat asam ( $\mathrm{pH}$ rendah) dan hipertonik meningkatkan risiko reflux meskipun diberikan dalam jumlah kecil sekitar $20 \mu \mathrm{l}(20)$, namun pada penelitian ini tidak dilakukan pengukuran $\mathrm{pH}$ dari seduhan tepung kulit mangga manalagi.

Berdasarkan hasil analisis kandungan serat yang dilakukan di Laboratorium Pusat Penelitian Pangan dan Gizi di Universitas Katolik Widya Mandala Surabaya menunjukkan bahwa tepung kulit mangga manalagi yang diberikan pada kelompok intervensi mengandung 55,5\% serat tak larut air dan 16,7\% serat larut air. Hal ini sejalan dengan penelitian sebelumnya yang menyatakan bahwa kandungan serat pada kulit mangga sekitar 40,5-72,5\% (23). Kelompok tikus perlakuan P4 mendapatkan seduhan tepung kulit mangga dengan berat tepung 1,6 gram yang mengandung 0,88 gram tak larut air dan 0,256 gram serat larut air dengan total serat sebesar 1,136 gram. Kandungan serat tersebut jika dikonversikan ke dosis manusia setara dengan 63,62 gram serat. Berdasarkan Angka Kecukupan Gizi, kebutuhan serat manusia berkisar 25-30 gram (24). Konsumsi serat yang berlebihan dapat berdampak pada penundaan pengosongan lambung sehingga menurunkan nafsu makan, rasa yang tidak nyaman pada saluran cerna seperti kembung dan konstipasi $(25,26)$. Pada penelitian ini, penurunan nafsu makan terjadi pada tikus yang mengalami drop out. Banyaknya subjek penelitian yang mengalami drop out merupakan keterbatasan dari penelitian ini sehingga berdampak pada pengurangan jumlah sampel yang mempengaruhi hasil penelitian. Dari penelitian ini dapat disimpulkan bahwa pemberian seduhan tepung kulit mangga manalagi dengan berat tepung 0,4 gram dapat menurunkan kadar MDA serum tikus putih yang diberi diet tinggi lemak, namun perlu dilakukan penelitian lebih lanjut terkait zat gizi dan non gizi yang kemungkinan memberikan dampak positif maupun negatif dari tepung kulit mangga manalagi terhadap kesehatan.

5. Taufik Y, Promosiana A, dan Atmojo HA. Statistik Produksi Holtikultura. Jakarta: Kementerian Pertanian Direktorat Jendral Holtikultura; 2014; p. 29-34.

6. Soemarno, Prasetyo B, Sukindar, dan Syafrial. Pengembangan Produk Unggulan Mangga di Kabupaten Madiun. AGRITEK. 2009; 17(5): 10012021.

7. Ajila CM, Aalami M, Leelavathi K, and Rao UJSP. Mango Peel Powder: A Potential Source of Antioxidant and Dietary Fiber in Macaroni Preparations. Innovative Food Science \& Emerging Technologies. 2010; 11(1): 219-224.

8. Lauricella M, Emanuele S, Calvaruso G, Giuliano M, and D'Anneo A. Multifaceted Health Benefit of Mangifera Indica L. (Mango): The Inestimable Value of Orchards Recently Planted In Sicilian Rural Area. 
Nutrients. 2017; 9(5): 1-14.

9. Ediriweera MK, Tennekoon $\mathrm{KH}$, and Samarakoon SR. A Review on Ethnopharmacological Applications, Pharmacological Activities, and Bioctive Compounds of Mangifera indica (Mango). Evidence-Based Complimentary and Alternative Medicines. 2017; 2017: 1-24.

10. Budin SB, Rahman WZA, Jubaidi FF, Yusof NLM, Taib IS, and Zainalabidin S. Roselle (Hibiscus Sabdiriffa) Polyphebol-Rich Extract Prevents Testicular Damage of Diabetic Rats. Journal of Applied Pharmaceutical Science. 2018; 8(2): 065-070.

11. Basu A, Newman ED, Bryant AL, Lyons TJ, and Betts NM. Pomegranate Polyphenols Lower Lipid Peroxidation in Adults with Type 2 Diabetes but Have No Effects in Healthy Volunteers: A Pilot Study. Journal of Nutrition and Metabolism. 2013; 2013: 17.

12. Ashoush IS and Gadallah MGE. Utilization of Mango Peels and Seed Kernels Powders as Sourcesof Phytochemicals in Biscuit. World Journal of Diary \& Food Science. 2011; 6(1): 35-42.

13. Sandhya M, Arun KM, Doddamani BR, Satyanaryana $\mathrm{U}$, and Shruti M. Circulatory Markers of Oxidative Stress and Dyslipidemia in Male Patients of Chronic Plaque Psoriasis. International Journal of Medicine and Public Health. 2015; 5(3): 208-212.

14. Dessi M, Noce A, Bertucci P, et al. Atherosclerosis, Dyslipidemia, and Inflammation: The Significant Role of Polyunsaturated Fatty Acids. International Scholarly Research Network Inflammation. 2013; 2013: 1-13.

15. Mallick AK, Das B, Ahsan M, Saxena S, Samanta S, and Kumari N. A Correlation Study between Lipid Peroxidation and Dyslipidemia in Postmenopausal Women. Scholars Journal of Applied Medical Sciences. 2015; 3(2B): 669-673.

16. Fiedor J and Burda K. Potential Role of Carotenoids as Antioxidants in Human Health and Disease. Nutrients. 2014; 6(2): 466-488.

17. Suaniti NM, Manurung $M$, and Utari NMM. Efek
Penambahan Antioksidan Ekstrak Metanol Kulit Buah Manggis (Garcinia mangostana L.) terhadap Perubahan Kadar FFA, Bilangan Asam, dan Bilangan Peroksidan Biodesel. Jurnal Kimia. 2017; 11(1): 49-55.

18. Harti LB, Suprihati S, and Kristina TN. Virgin Coconut Oil (VCO) Treatment to Reduce the Level of LOX-1 and Lp- PLA2: Experimental Study of High-Fat Diet on Wistar Rats. International Food Research Journal. 2018; 25(5): 1925-1929.

19. Cinelli P, Rettich A, Seifert B, Burki K, and Arras M. Comparative Analysis and Physiological Impact of Different Tissue Biopsy Methodologies Used for the Genotyping of Laboratory Mice. Laboratory Animals. 2007; 41(2): 174-184.

20. Damsach S, Eichenbaum G, Tonelli A, et al. GavageRelated Reflux in Rats: Identification, Pathogenesis, and Toxicological Implications (Review). Toxicologic Pathology. 2011; 39(2): 348-360.

21. Jones CP, Boyd KL, and Wallace JM. Evaluation of Mice Undergoing Serial Oral Gavage While Awake or Anesthetized. Journal of the American Association for Laboratory Animal Science. 2016; 55(6): 805-810.

22. Turner PV, Vaughn E, Neilson JS, Ovari J, and Leri F. Oral Gavage in Rats: Animal Welfare Evaluation. Journal of the American Association for Laboratory Animal Science. 2012; 51(1): 25-30.

23. Ajila CM dan Rao UJSP. Mango Peel Dietary Fibre: Composition and Associated Bound Phenolics. Journal of Functional Food. 2013; 5(1): 444-450.

24. Kementerian Kesehatan Republik Indonesia. Peraturan Menteri Kesehatan RI No. 75 tentang Angka Kecukupan Gizi yang Dianjurkan bagi Bangsa Indonesia. Jakarta: Kementerian Kesehatan RI; 2013.

25. Li YO and Komarek AR. Dietary Fibre Basics: Health, Nutrition, Analysis, and Applications. Food Quality and Safety. 2017; 1: 47-59.

26. Sun-Ho KS, Tan CYM, Daud MAM, and Seow-Choen F. Stopping or Reducing Dietary Fiber Intake Reduces Constipation and Its Associated Symptoms. World Journal of Gastroenterology. 2012; 18(33): 45934596 